\title{
Influence of Nitrogen and Phosphorus on Size and Fresh Weight of Corm in Gladiolus grandiflorus L. cv. White Prosperity
}

\author{
K.S. Sabastian ${ }^{1 *}$, Khamrang Mathukmi ${ }^{2}$, Nellisha Ngoruw Moyon ${ }^{1}$, \\ Jonah Dakho ${ }^{1}$ and Haribhushan Athokpam ${ }^{3}$
}

${ }^{1}$ Department of Horticulture, School of Agricultural sciences and Rural Development, Medziphema Campus, Nagaland University, Nagaland 797106, India

${ }^{2}$ Ethno Medicinal Research Centre, Hengbung, Senapati District, PO Kangpokpi - 795129, Manipur, India

${ }^{3}$ Krishi Vigyan Kendra (Farm Science Centre), Hengbung, Senapati District, P.O. Kangpokpi-795129, Manipur, India

*Corresponding author

\section{A B S T R A C T}

\begin{tabular}{|l|}
\hline Key w or d s \\
Nitrogen, \\
Phosphorus, \\
Gladiolus and Corm \\
\hline Article Info \\
\hline Accepted: \\
20 April 2018 \\
Available Online: \\
10 May 2018 \\
\hline \hline
\end{tabular}

Gladiolus occupies an important place among the most popular bulbous ornamental plants. To optimize the production technology for this important plant, a field experiment was conducted at the Horticulture Experimental Farm, School of Agricultural sciences and Rural Development, Nagaland University, Medziphema Campus to study the effect of nitrogen and phosphorus on size and fresh weight of corm production in Gladiolus grandiflorus $\mathrm{Cv}$. White Prosperity. The experiment was laid out in Randomized Block Design with two factors viz. nitrogen $(0,250,300$ and $350 \mathrm{~kg} / \mathrm{ha})$ and phosphorus $(0,150$, 200 and $250 \mathrm{~kg} / \mathrm{ha}$ ), replicated thrice. Data was recorded for different parameters including corm size and fresh weight during the course of the study and statistically analyzed. Application of nitrogen and phosphorus @ 300 and $200 \mathrm{~kg} \mathrm{ha}^{-1}$ results in better production of corms in terms of size and weight respectively. For better vegetative growth and quality flower production, nitrogen and phosphorus can be applied @ 300 and $200 \mathrm{~kg} \mathrm{ha}^{-1}$ respectively.

\section{Introduction}

Gladiolus (Gladiolus grandiflorus L.) is a native of South Africa and belongs to family Iridaceae and subfamily oxioideae. The name gladiolus was coined by Pliny the Elder (A.D. 23-79) to describe the shape of the leave which resembles that of sword (Latin word "gladius" meaning sword). It is also called by name sword lily, cornflag. Gladiolus are said to be cultivated since the day of ancient Greece. Gladiolus is a very popular bulbous flowering plant. It is an important commercial flower crop and having pivotal place as cut flower both in domestic and international market. It is relatively easy to grow and is ideal for bedding and exhibition. The fascinating spikes bear a large number of florets, which exhibit varying sizes and forms with smooth, ruffled or deeply crinkled petals. 
The flowers are used in flower arrangement, bouquets and for indoor decorations. It ranks next to tulip in the Netherland and other Europeans countries in trade for use as cut flowers of bulbous crops and fourth in international trade of ornamental for cut flowers. Its keeping quality makes it a very commercial cut flower after rose. Gladiolus occupies first place in term of returns as compared to other cut flowers (Singh, 2006).

Gladiolus occupies an important place among the most popular bulbous ornamental plant. It is a universal and versatile flowering plant and hold an important place for a number of reasons specially durability and market value. Among the bulbous flowering ornamentals, gladiolus is the most ideal one mainly for its garden display and cut flower with it majestic spike having massive florets of wide spectrum of colour, attractive shapes, varying size and excellent keeping quality. Gladiolus, a potential flower crop form a part of floriculture industry in the country. It is estimated that throughout India gladiolus is grown in about 1167 ha, producing 5070 MT loose flower and 9289 MT cut spike (Anonymous, 2015). In India, gladiolus is commercially grown in West Bengal, Maharashtra, Uttar Pradesh, Uttaranchal, Punjab, Haryana, Sikkim, Jammu and Kashmir, Karnataka, Gujarat, Himachal Pradesh, Tamil Nadu, Madhya Pradesh, Delhi and Rajasthan. Gladiolus is available virtually throughout the year as growers stagger the corm planting from July to December to harvest the flower from September to May. The high remuneration in this market is obtained from winter grown gladiolus.

Nutrition is one of the utmost important aspects, which directly influences spike yield and quality. Each nutrient performs certain specific function in the plant and no nutrient can be substitute by another. Nitrogen and phosphorus are among the common major nutrient which are essential for growth and development of all plant species. Gladiolus being highly responsive crop to nutrition requires large doses of macro nutrients viz., nitrogen, phosphorus and potassium (Shankar and Dubey, 2005).

Nitrogen is a vitally important plant nutrient, plant normally contain $1-5 \%$ by weight of this nutrient. It is an essential constituent of protein and is present in many other compound of great physiological importance in plant metabolism. Nitrogen is an integral part of chlorophyll, which is the primary absorber of light energy needed for photosynthesis. Nitrogen imparts vigorous vegetative growth, dark green colour to the plants, it produce early growth and also delays in maturity of plants. Nitrogen also governs the utilization of potassium, phosphorus and other elements. The supply of nitrogen is related to carbohydrates utilization, when nitrogen supplies are sufficient carbohydrates will be deposited in vegetative cell which will cause them to thicken (Das, 2014). Application of nitrogen significantly increases the number of leaves/shoots, leaf area/plant, corm size, weight of corm and cormel/mother corm, cormels/plant and propagation coefficient in gladiolus (Kumar and Mishra, 2011).

Phosphorus has a great role in energy storage and transfer. An adequate supply of phosphorus in early stage of plant life is important for the reproductive part of the plants. Phosphate compound acts as energy currency within the plants and essential constituent of majority enzymes which are of great importance. Phosphorus is closely related to cell division and development, it stimulate early root development, growth and thereby help to established seedling quickly. In gladiolus, phosphorus application significantly increased plant height, spike length and number of florets (Bawaja et al., 
2001). The vegetative parameters like plant height, number of leaves, leaf area, dry weight of leaves, dry weight of flower, growth parameters like leaf area index (LAI), crop growth rate (CGR) and net assimilation rate (NAR) are increased with the application of phosphorus (Chandana and Dorajeerao, 2014).

In gladiolus plant height, leaf area, days to first floret opening, spike length and longevity of intact spike, increases with increasing levels of both nitrogen and phosphorus (Haokip and Singh, 2005). Nitrogen and phosphorus significantly influenced the physiological parameters such as vase life of spike, bud appearance, duration of flowering, number of flowering, spike length, number of florets per spike, and diameter and length of floret. It also influence the biochemical parameters like chlorophyll content in leaves, anthocyanin contents in petals, nitrogen and phosphorus content in leaves (Chouhan et al., 2014).

Cultivation of gladiolus in Nagaland is limited to few growers, however with the favorable prevailing agro-climatic condition; there is an immense scope and potential for commercializing gladiolus cultivation. In addition, progressive markets within and outside the state makes it a potential crop for earning profits. Lack of scientific agro techniques especially the package of fertilization dose in gladiolus appears to be the bottleneck for the commercialization and economic returns of gladiolus to the growers of the region. Therefore it was felt pertinent to undertake the present investigation to ascertain and recommend the standard agro technique specially the package of fertilization in gladiolus.

\section{Materials and Methods}

The present investigation was carried out in the Horticulture Experimental Farm, School of
Agricultural Sciences and Rural Development (SASRD), Nagaland University, Medziphema, during the year 2014 to 2015 . The experiment consists of four levels of nitrogen i.e., $\mathrm{N}_{0}: 0$, $\mathrm{N}_{2}: 250, \mathrm{~N}_{3}: 300$ and $\mathrm{N}_{4}: 350 \mathrm{~kg}$ Nitrogen/ha and four level of phosphorus $\mathrm{P}_{1}: 0, \mathrm{P}_{2}: 150, \mathrm{P}_{3}$ : 200 , and $\mathrm{P}_{4}: 250 \mathrm{~kg}$ phosphorus/ha with three replication and was laid out in Randomized Block Design. The treatment combinations are:

$\mathrm{T}_{1}=\mathrm{N}_{0} \mathrm{P}_{\mathrm{O}} ; \mathrm{T}_{2}=\mathrm{N}_{0} \mathrm{P}_{1} ; \mathrm{T}_{3}=\mathrm{N}_{0} \mathrm{P}_{2} ; \mathrm{T}_{4}=\mathrm{N}_{0} \mathrm{P}_{3}$ $\mathrm{T}_{5}=\mathrm{N}_{1} \mathrm{P}_{0} ; \mathrm{T}_{6}=\mathrm{N}_{1} \mathrm{P}_{1} ; \mathrm{T}_{7}=\mathrm{N}_{1} \mathrm{P}_{2} ; \mathrm{T}_{8}=\mathrm{N}_{1} \mathrm{P}_{3}$ $\mathrm{T}_{9}=\mathrm{N}_{2} \mathrm{P}_{0} ; \mathrm{T}_{10}=\mathrm{N}_{2} \mathrm{P}_{1} ; \mathrm{T}_{11}=\mathrm{N}_{2} \mathrm{P}_{2} ; \mathrm{T}_{12}=\mathrm{N}_{2} \mathrm{P}_{3}$ $\mathrm{T}_{13}=\mathrm{N}_{3} \mathrm{P}_{0} ; \mathrm{T}_{14}=\mathrm{N}_{3} \mathrm{P}_{1} ; \mathrm{T}_{15}=\mathrm{N}_{3} \mathrm{P}_{2} ; \mathrm{T}_{16}=\mathrm{N}_{3} \mathrm{P}_{3}$

A basal dose of $8 \mathrm{~kg}$ well rotten FYM was applied per plot during the final land preparation.

A constant dose of Potassium @ $200 \mathrm{~kg} / \mathrm{ha}$ in the form of MoP were applied on the entire plot as basal dose. Four levels of nitrogen which were $0 \mathrm{~kg} / \mathrm{ha}$ (control); $250 \mathrm{~kg} / \mathrm{ha}, 300$ $\mathrm{kg} / \mathrm{ha}$ and $350 \mathrm{~kg} / \mathrm{ha}$ were applied in the form of urea. Nitrogen was applied in two split doses, the $1^{\text {st }}$ dose at 20 DAP and the $2^{\text {nd }}$ at 40 DAP. Phosphorus were also applied in four levels, $0 \mathrm{~kg} / \mathrm{ha}$ (control); $150 \mathrm{~kg} / \mathrm{ha}, 200 \mathrm{~kg} / \mathrm{ha}$ and $250 \mathrm{~kg} / \mathrm{ha}$.

Total phosphorus was applied at the time of planting as basal dressing. The diameter and fresh weight of the corm was measured with the help of Vernier caliper and electronic weighing balance respectively and average was work out and represented in centimeter $(\mathrm{cm})$ and gram $(\mathrm{g})$.

The collected data on the different parameter of study were statistically analyzed as per procedure given by Panse and Sukhatme (1978) and the treatment variance was tested against error mean square by applying Fischer Snedecore ' $F$ ' test of probability at 0.5 percent level of significance. 


\section{Results and Discussion}

\section{Size of the corm}

Table 1 and Figure 1 depict the result of the influence of graded level of nitrogen and phosphorus and their interaction on the size of the corm. Various level of nitrogen significantly increased the size of the corm. The largest corm size $(5.57 \mathrm{~cm})$ was recorded in $300 \mathrm{~kg} \mathrm{~N} \mathrm{ha}^{-1}$ which is statistically at par with $350 \mathrm{~kg}$ nitrogen $\mathrm{ha}^{-1}(5.48 \mathrm{~cm})$. The smallest $(5.09 \mathrm{~cm})$ corm size was recorded in the control. The result demonstrate that application of nitrogen significantly increase the diameter of the corms, also higher level of nitrogen increase the total leaves and leaves area of the plant causing high dry matter accumulation in the plant and its greater mobilization in corms and cormels hence give better yield. The present experimental findings are in line with the findings of Baboo and Singh (2006) and Gaurav (2011) in gladiolus and Gayathiri and Anburani (2011) in glory lily.

It was also observed that phosphorus fertilization show significant difference on the size of the corm. The largest corm size (5.52 $\mathrm{cm}$ ) was recorded in $200 \mathrm{~kg} \mathrm{P}_{2} \mathrm{O}_{5} \mathrm{ha}^{-1}$ which was at par with $250 \mathrm{~kg} \mathrm{P}_{2} \mathrm{O}_{5} \mathrm{ha}^{-1}$ and $150 \mathrm{~kg}$ $\mathrm{P}_{2} \mathrm{O}_{5}$ ha $^{-1}(5.49 \mathrm{~cm}$ and $5.34 \mathrm{~cm})$ respectively. The smallest corm size $(5.14 \mathrm{~cm})$ was recorded in control. The increase in diameter of the corms might be due to the fact that higher level of phosphorus increases total leaves and leaves area of the plant causing high dry matter accumulation in the plant thus, leads to better yield in corm. The present experimental finding is in confirmation with the finding of Kumar and Mishra (2011) in gladiolus and Kadu et al., (2009) in tuberose $\mathrm{Cv}$. Single. The interaction of nitrogen and phosphorus levels did not show any significant effect on the size of the corm.

Table.1 Response of graded level of nitrogen and phosphorus on the corm characteristic of Gladiolus grandiflorus $\mathrm{L}$. Cv. white prosperity

\begin{tabular}{|c|c|c|}
\hline Treatment & Size of the corm $(\mathrm{cm})$ & Fresh weight of corm (g) \\
\hline Control $\left(\mathbf{N}_{0}\right)$ & 5.09 & 55.40 \\
\hline $250 \mathrm{~kg} \mathrm{~N} \mathrm{ha}^{-1}\left(\mathrm{~N}_{1}\right)$ & 5.35 & 58.40 \\
\hline $300 \mathrm{~kg} \mathrm{~N} \mathrm{ha}^{-1}\left(\mathrm{~N}_{2}\right)$ & 5.57 & 60.85 \\
\hline $350 \mathrm{~kg} \mathrm{~N} \mathrm{ha}^{-1}\left(\mathrm{~N}_{3}\right)$ & 5.48 & 60.15 \\
\hline CD 5\% & 0.21 & 2.82 \\
\hline Control $\left(\mathbf{P}_{\mathbf{0}}\right)$ & 5.14 & 56.26 \\
\hline $150 \mathrm{~kg} \mathrm{Pha}^{-1}\left(\mathrm{P}_{1}\right)$ & 5.34 & 58.03 \\
\hline $200 \mathrm{~kg} \mathrm{P} \mathrm{ha}^{-1}\left(\mathrm{P}_{2}\right)$ & 5.52 & 60.45 \\
\hline $250 \mathrm{~kg} \mathrm{Pha}^{-1}\left(\mathrm{P}_{3}\right)$ & 5.49 & 60.07 \\
\hline CD $5 \%$ & 0.21 & 2.82 \\
\hline \multicolumn{3}{|l|}{ Interaction } \\
\hline $\mathbf{N} \times \mathbf{P}$ & NS & NS \\
\hline
\end{tabular}


Fig.1 Response of nitrogen and phosphorus doses on size of the corm

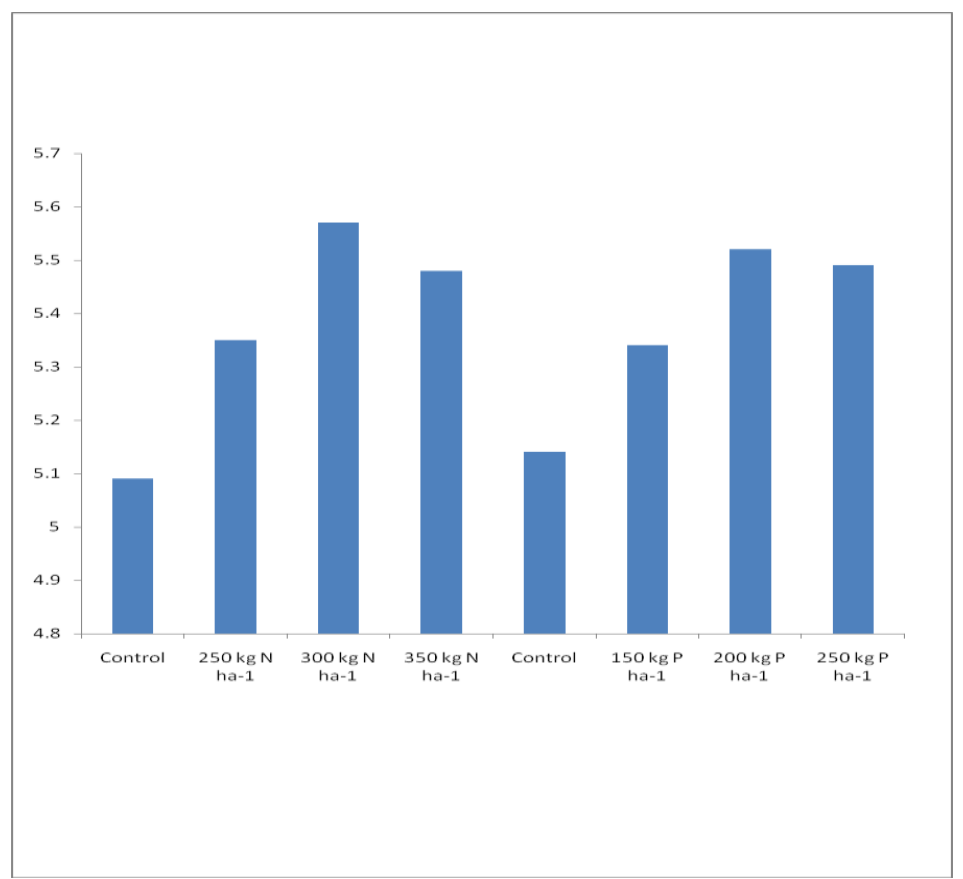

Fig.2 Response of nitrogen and phosphorus doses on the fresh weight of corm

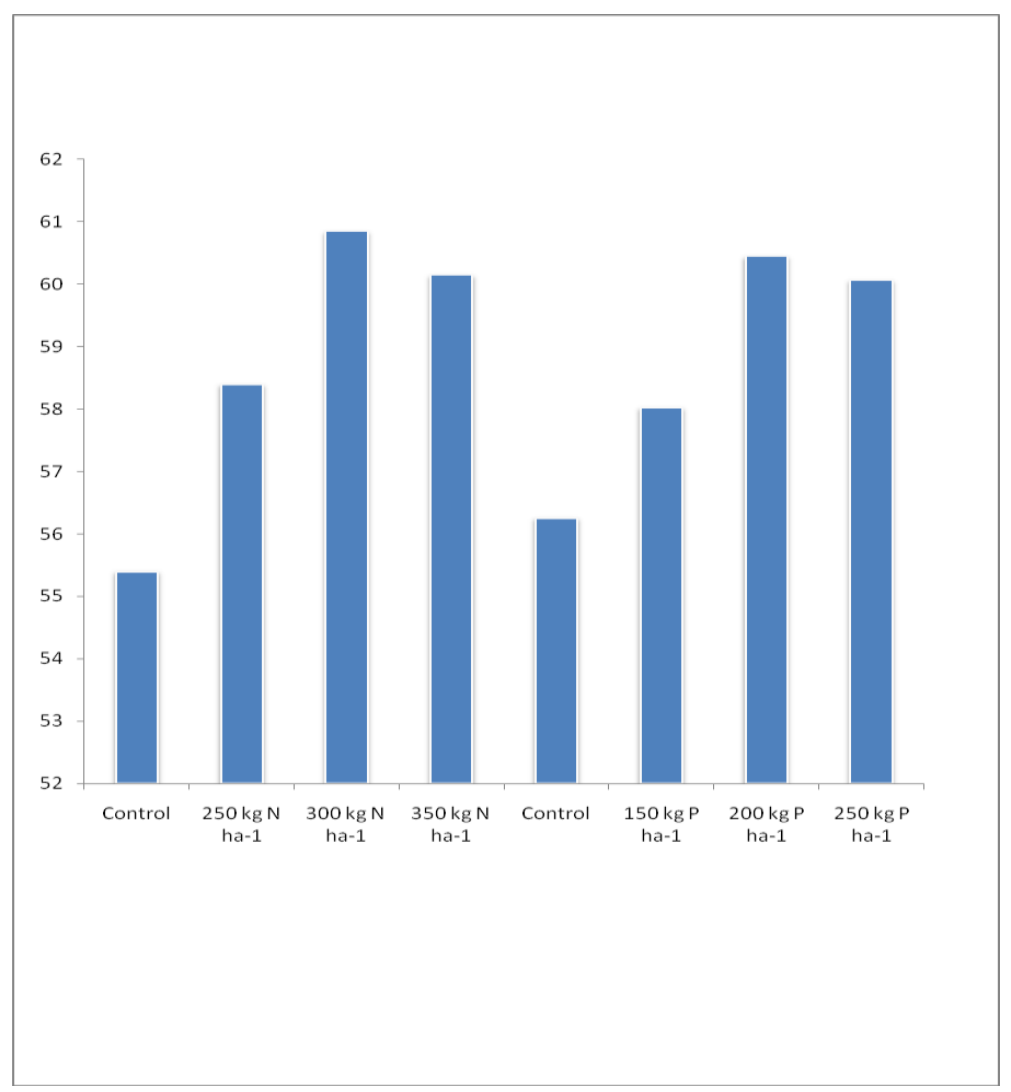




\section{Fresh weight of the corm}

Table 1 and Figure 2 depict the result of the influence of nitrogen, phosphorus and their interaction on fresh weight of corm. Application of nitrogen in varied doses significantly increases the fresh weight of the corm. The heaviest weight of the corm $(60.85$ g) was recorded in $300 \mathrm{~kg} \mathrm{~N} \mathrm{ha}^{-1}$ which was statistically at par with in $350 \mathrm{~kg} \mathrm{~N} \mathrm{ha}^{-1}$ and $250 \mathrm{~kg}$ nitrogen $\mathrm{ha}^{-1}(60.15 \mathrm{~g}$ and $58.40 \mathrm{~g})$ respectively. The least weight of the corm $(55.40 \mathrm{~g})$ was recorded in $250 \mathrm{~kg} \mathrm{~N} \mathrm{ha}^{-1}$. The present experimental findings are in conformity with the findings of Baboo and Singh (2006) in gladiolus Cv. Jester

Application of phosphorus at various levels had a significant influence on the fresh weight of the corm. The heaviest weight of the corm $(60.45 \mathrm{~g})$ was recorded in $200 \mathrm{~kg} \mathrm{P}_{2} \mathrm{O}_{5} \mathrm{ha}^{-1}$ which was at par with $250 \mathrm{~kg} \mathrm{P}_{2} \mathrm{O}_{5} \mathrm{ha}^{-1}$ and $150 \mathrm{~kg} \mathrm{P}_{2} \mathrm{O}_{5} \mathrm{ha}^{-1}(60.07 \mathrm{~g}$ and $58.03 \mathrm{~g}$ ) respectively. The minimum fresh weight $(56.26 \mathrm{~g})$ of corm was recorded in control. The present experimental finding is in conformity with the finding of Chandana and Dorajeerao (2014) in gladiolus $\mathrm{Cv}$. White prosperity, Kumar and Mishra (2011) in gladiolus and Kadu et al., (2009) in tuberose Cv. Single. The interaction effect between different levels of nitrogen and phosphorus failed to show any significant effect on the weight of the corm.

On the basis of results obtained from this study, it may be concluded that application of nitrogen@300 kg ha ${ }^{-1}$ and phosphorus@ $200 \mathrm{~kg} \mathrm{ha}^{-1}$ has significant impact on growth and development of corm which ultimately results in vigorous vegetative growth and quality flower production. Thus, application of nitrogen@300 kg ha ${ }^{-1}$ and phosphorus@ $200 \mathrm{~kg} \mathrm{ha}^{-1}$ is recommended for Gladiolus grandiflorus $\mathrm{cv}$. White Prosperity.

\section{Acknowledgement}

The authors are thankful to the Department of Horticulture, School of Agricultural Sciences and Rural Development (SASRD), Nagaland University for providing the required research facilities and all those who give guidance and assistance for the successful completion of the research work.

\section{References}

Anonymous, 2015. National Horticulture Board (NHB).

Baboo, R., and Singh, R. D. 2006. Response of nitrogen, phosphorus and corm size on flowering and corm production in gladiolus. J ornamental Hort., 9: 66-68.

Bawaja, H. S., Kashyap, A. S., Panwar, A. S., and Shulka, Y. R. 2001. Response of gladiolus to nitrogen and phosphorus under the mid-hill conditions of HP Himalayas. Indian $\mathrm{J}$ Hill Farming 14:88-91.

Chandana, K., and Dorajeerao, A. V. D. 2014. Effect of graded levels of nitrogen and phosphoruson growth and yield of gladiolus (Gladiolus grandiflorus L.) Cv. White Prosperity in coastal A.P. India. Plant archives 14: 143-150.

Chouhan, P. Vidhya, S. M., and Vijay, R. 2014.Effect of NPK on PhysicoChemical Parameters of Gladiolus (Gladiolus hybridus Hort.) Cv. White Prosperity. Int J Sci Res 4: 50-53

Das, D. K., 2014. Introductory to Soil Science. Kalyani Publisher 20: 351-353

Gaurav, S. P. S. 2011. Response of macronutrient application of growth and flowering attributes of gladiolus and its economics in mango orchard. Plant Archives 11: 249-251.

Gayathiri, M. Anburani, A. 2011. Effect of graded levels of nitrogen and phosphorus on growth parameters of 
glory lily (Gloriosa superb L.). Asian J of Hort6: 481-483.

Haokip, N., and Singh, U. C. 2005.Response of nitrogen and phosphorus on growth and flowering parameters in gladiolus. $\mathbf{J}$ ornamental Hort8:314-315.

Kadu, A. P., Kadu, P. R. and Sable, A. S. 2009.Effect of nitrogen, phosphorus and potassium on growth, flowering and bulb production in tuberose $\mathrm{Cv}$. Single. J of Soils and Crops 19:367-370.

Kumar, R., and Mishra, R. L. 2011. Studies on nitrogen application in combination with phosphorus or potassium on gladiolus Cv. Jester Gold. Indian J Hort 68: 535-539.

Shankar, D., and Dubey, P. 2005. Effect of NPK, FYM and NPK + FYM on growth, flowering and corm yield of gladiolus when propagated through cormels. J. Soils and Crops15 (1): 3438.

Singh, A. K., 2006. Flower Crops cultivation and management. New India Publishing Agency 11: 148-166.

\section{How to cite this article:}

Sabastian, K.S., Khamrang Mathukmi, Nellisha Ngoruw Moyon, Jonah Dakho and Haribhushan Athokpam. 2018. Influence of Nitrogen and Phosphorus on Size and Fresh Weight of Corm in Gladiolus grandiflorus L. cv. White Prosperity. Int.J.Curr.Microbiol.App.Sci. 7(05): 2892-2898. doi: https://doi.org/10.20546/ijcmas.2018.705.337 